\title{
IMPROVING SOCIETY EMPOWERMENT OF TRADITIONAL OIL MINERS OF OLD WELLS IN WONOCOLO
}

\author{
Ani Siti Hartati ${ }^{1}$, Sri Kussujaniatun ${ }^{2}$, Marita ${ }^{3}$ \\ ${ }^{1}$ Faculty of Economic, Pembangunan Nasional "Veteran" University, Yogyakarta Indonesia \\ ${ }^{2}$ Faculty of Economic, Pembangunan Nasional "Veteran" University, Yogyakarta Indonesia \\ ${ }^{3}$ Faculty of Economic, Pembangunan Nasional "Veteran" University, Yogyakarta Indonesia
}

\begin{abstract}
The issue of this research is related to the variables which are affecting the empowerment of the traditional oil miners of old wells in Wonocolo, Bojonegoro, East Java, Indonesia. The aim of this research is to analyze the influence of the variables of physical, human and social capital also the ability of empowerment actors towards the variable of society empowerment. Research design of this study is descriptive analytic which is expected to provide an explanation of the phenomenon of community empowerment process and to direct various government policies related to behavioral aspects of empowerment actors. The data used are primary data, collected using survey method through questionnaire. Regression analysis technique is used to analyze the data. Research findings show that there are significant influences of the four variables towards society empowerment. The most dominating variable towards society empowerment is the social capital variable, while the ability of empowerment actors has the lowest influence towards society empowerment. The implementation of the results is that empowerment needs the development of human, social, and physical capital and it will be better if the empowerment is supported by the development of empowerment actors' ability. It is expected that the government of Bojonegoro can support the implementation of society empowerment. Thus, it can increase the society income especially for the traditional oil miners of old wells.
\end{abstract}

Keywords: community empowerment, physical capital, human capital, social capital, ability of empowerment 


\section{Background}

Bojonegoro, East Java, Indonesia is gifted with marvelous nature richness potentials. Wonocolo is one of the regions in Bojonegoro with the oil mining area that now is still developed and managed using traditional method. This region is located approximately $60 \mathrm{~km}$ from the center of Bojonegoro city and it is closed to the border of Blora, Central Java (Local Government Mid-term Development Plan, 2013). Teksas, Wonocolo is selected and proposed as geosite in Petroleum Geoheritage Bojonegoro, since in this place there are rocks that represent the system of petroleum and there is a traditional oil mining in old wells made by the Netherlands in their colonization era. The previous research conducted by Kussujaniatun (2017) shows the importance of improving the social interaction, accountability, integrity, empathy, and motivation in improving the society empowerment. It is expected that those factors can improve the economics of the region. The goal is to create independents individuals and society, including the independence in their way of thinking, act, and controlling what they are doing. Society with their high empowerment is the societies that are physically and mentally healthy, educated and strong, and possessing the intrinsic values that become the source of their empowerment, such as the virtues of togetherness and cooperation (Zubaidi, 2013). The miners do the mining process using traditional method by utilizing the cars' machines and logs from teaks. The top of Wonocolo anticline is located $450 \mathrm{~m}$ above the surface of the sea, while the shallowest drilling is around $200 \mathrm{~m}$ from the top of the fold. Besides its location that is similar to the location of oil mining in Texas, America, now the location of Teksas in Wonocolo has served as the educational tourism. There is Rumah Singgah (rest area) that serves as learning center about oil and its exploitation in Wonocolo. Besides, there is also adventure tourism using Jeeps around this region (Society and Village Empowerment Department of Bojonegoro, 2014).

The numerous tourism potentials should be in line with the development of the society that must be able to utilize all the potentials and develop them into their leading products of the region. It is expected that from the products created, Wonocolo is not only famous for its Teksas, but also for its tourism potentials and the prominent souvenirs offered, such as oil souvenirs and miniatures from the teaks' logs. However, the problem is that right now not many people try to develop the potentials, and this is supported by the research result by Anis Sri Hartati (2017) that the performance of the oil miners to utilize the old wells cannot be fully expected to support their finance and to improve their prosperity. Society empowerment needs to be done, not only to make the society aware of the potentials in their region, but also to enable them to try to use the potentials as a way to improve the economics of the society and the region, which can be started by creating small business. Based on research result conducted 


\section{October 19-21, 2018 Munich, Germany}

by Kesi Widjajanti (2011), physical capital and human capital are significant aspects in society empowerment. The research's interest is related to the variables influencing the empowerment level of the society and the formulation of the empowerment model based on the condition of the location. The objective of the research is to analyze the influence of the physical capital, human capital, social capital, and the ability of the actors towards the society empowerment. It is expected that based on the results of this research together with the government especially the local government of Wonocolo, the society empowerment can be improved.

The results of previous research conducted by Kussujaniatun (2016) are 1) tourism potentials mapping in Margomulyo, Bojonegoro; the high tourism potential of teaks' roots shows that there is a need to develop the local wisdom and harmonization between the visitors and the nature, 2) teaks' roots potential mapping; the mapping shows the high nature potential of the superior commodity of the teaks' roots products and the lengthy marketing distribution. Society empowerment is an effort to build the society's own attraction by encouraging, motivating, and arousing their awareness of the potentials that they have, as wells as developing the potentials (Theresia, Aprillia, 2014). Society empowerment can be realized by active participation from the society that is facilitated by the existence of the actors of the empowerment. The main target of the society empowerment if those who are weak, having no power or ability to access the productive resources, or those who are left behind in their development.

The final goal of the society empowerment process is to make the society independent, so that they can improve the finances of their family and optimize the resources that they have (Kesi Widjajanti, 2011). Besides, it can be done by involving the women as well, so that the women can support the improvement of their families' finances. The research about women empowerment has been done by Kussujaniatun (Kussujaniatun, 2014).

Based on some definitions about empowerment suggested above, then it can be concluded that basically, empowerment is a process and an effort to obtain or to give the power or ability to the individuals and the weak society so that they can identify, analyze, and set their needs and potentials, as well as the problems that they face, and then choose the options of the solutions by optimizing the resources and potentials independently. The research variables consist of physical capital, human capital, social capital, and the ability of the empowerment's actors. Physical capital is the facilities or assets used as the tools and the main supports in conducting a process, such as buildings, roads, equipment, machines, and so on. The indicators of the physical capital are: (a) facilities in farming production, (b) facilities and infrastructures in education, (c) facilities and infrastructures in health, (d) facilities and infrastructures in economics, and (f) facilities and infrastructures in transportation. Human capital is the assets related to the ability to do certain activities. The indicators of the human capital are: (a) 


\section{HPSCONF

education level, (b) health rate, and (c) ability to build interactions among people. Social capital is the norm or values understood by the society that can strengthen the positive social network or work network, in terms of realizing the goal to create the social value. The indicators shown by asking questions related to the existence of (a) social network or work network, (b) trust level among people, (c) obedience to the norms, (d) care of others, and involvement in social organization activities. Empowerment actors' abilities are the abilities of the actors of the empowerment that are expected to be able to empower the society. The abilities include (a) knowledge/ cognitive, (b) affective, (c) psychomotor skills. Society empowerment is the power and the ability of the society to identify the potentials and the problems and then choose the options of the solutions independently. The indicators of the empowerment are (a) the ability to make decision, (b) independency, and (c) the ability to create businesses for the future (Kesi Widjajanti, 2011).

\section{Methods}

The research design is descriptive, and it is expected to explain the phenomenon of the society empowerment. The type of data used in this research is primary data that is obtained directly by distributing questionnaires. The samples of the research are 197 traditional oil miners in Wonocolo. The variables of the research are dependent variable of society empowerment, and independent variables including physical capital (X1), human capital (X2), social capital (X3), and the ability of the empowerment actors (X4). The research employs Multiple Linear Regression technique to analyze the data. It is one of the statistical analyses commonly used to analyze the influence of two or more variables. According to Drapper \& Smith, regression analysis can be used to analyze data and take the meaningful conclusion of the dependency relationship between independent and dependent variables in the form of equation (Drapper \& Smith in Rahmadeni, 2014).

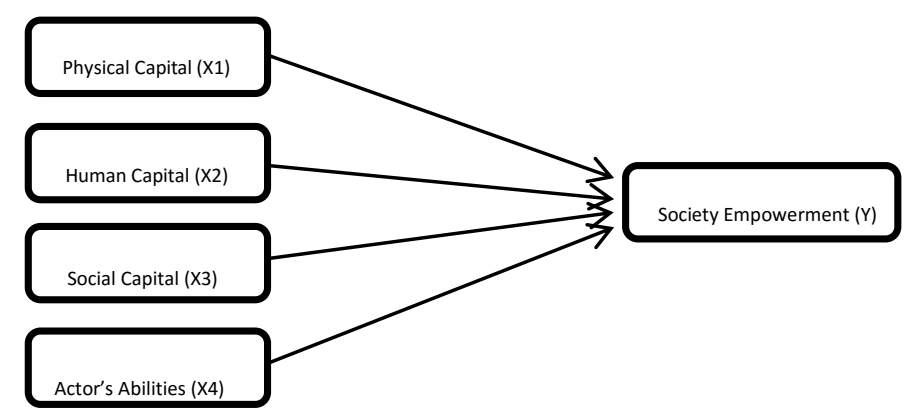

Fig. 1: Research Framework

The influence of physical capital, human capital, social capital and actors' abilities on the society empowerment 


\section{Results}

\subsection{Results}

The description result of this research shows that the respondents, who are the traditional oil miners, are mostly male $(81,2 \%)$ and $73 \%$ of them are in the range of $34-60$ years old with the education level of Junior high school (59\%) and elementary school (31\%).

The availability of the physical capital such as facilities and infrastructures for productions, education, health, economics, communication, and transportation is sufficient to support the activities of the miners $(20,06 \%)$. The condition of human capital such as education level, health rate, and the ability to build interaction among others is still low $(19,4 \%)$. The condition of the social capital of the miners is high $(27,3 \%)$, in which they work together, trust each other, are obedient to the norms, care of each other, and are involved in social organization activities in their surroundings. Meanwhile, the ability of the actors of the empowerment is still low $(15,7 \%)$ since their cognitive knowledge, affective behavior, and psychomotor skills are still insufficient. Most of the miners living in the mining area are still less empowered (17, 4\%).

To find out whether there is influence between the independent variables, which consist of physical capital (X1), human capital (X2), social capital (X3), and actors' ability (X4), and the dependent variable of society empowerment (Y), the Multiple Regression Test is conducted. The coefficient values of the regression are presented in Table 1.

Table 1. Regression Coefficient Value between independent variable $\mathrm{X}$ and dependent variable $\mathrm{Y}$

\begin{tabular}{|r|c|c|c|c|c|}
\hline Model & \multicolumn{1}{|c|}{$\begin{array}{c}\text { Unstandardized } \\
\text { Coefficients }\end{array}$} & $\begin{array}{c}\text { Standardiz } \\
\text { ed } \\
\text { Coefficient } \\
\mathrm{s} \\
\text { Beta }\end{array}$ & Sig. & \\
\cline { 1 - 5 }$\left(\begin{array}{c}\text { Consta } \\
\mathrm{nt})\end{array}\right.$ & .983 & .776 & & 1.267 & .207 \\
$\mathrm{KP}$ & .115 & .033 & .233 & 3.520 & $.001 * *$ \\
$\mathrm{MM}$ & .117 & .050 & .185 & 2.358 & $.019 *$ \\
\hline
\end{tabular}


October 19-21, 2018 Munich, Germany

\begin{tabular}{|c|c|c|c|c|c|} 
MS & .228 & .055 & .341 & 4.136 & $.000 * * *$ \\
MF & .136 & .074 & .112 & 1.824 & $.070^{*}$ \\
\hline
\end{tabular}

Source: analysis result of the primary data

Note: *significant at a 0.05

** very significant at a 0.01

KP: actors' ability

MM: human capital

MS: social capital

MF: physical capital

The result of the regression test (Table 1) shows that the variables of physical capital, human capital, social capital, and actors' ability have positive influence toward the empowerment level of the society.

It can be concluded that all of the independent variables influence the dependent variable that can be seen from the significance value and beta coefficient. The higher availability and condition of the physical capital, human capital, social capital, and actors' ability are, the higher empowerment level of the society will be. The equation of the regression is as follows:

$$
\mathrm{Y}=0.983+0.115 \mathrm{X} 1+0.228 \mathrm{X} 2+0.117 \mathrm{X} 3+0.136 \mathrm{X} 4
$$

Based on the regression model, it can be explained that in improving the empowerment level of the society, the stakeholders, especially the government need to regularly develop the involvement of the society in improving the physical capital, human capital, social capital, and actors' ability in empowerment. The high physical capital, human capital, social capital, and actors' ability will automatically increase the society empowerment. However, based on Table 1 , the significance level of the actors' ability is still less significant. It means that the influence of this variable does not influence significantly to the society empowerment of the miners of the old wells in Wonocolo, Bojonegoro.

Social capital has the dominant role in empowering the society, and therefore there is a need to maintain the social capital. Social capital consists of (a) social network or work network, (b) trust level among people, (c) obedience to the norms, (d) care of others, and involvement in social organization activities.

\subsection{Discussion}




\subsubsection{The influence of Physical Capital on Society Empowerment}

Based on the research result, it shows that the variable of physical capital has positive influence on the variable of society empowerment. It can be seen from Table 1 that shows the interaction value of 0,136 . It means that if the physical capital is increased, it will strengthen the society empowerment. Physical capital can be improved by repairing and improving the facilities and infrastructures in productions, education, health, economics, communication, and transportation that support the activities of the miners, so that eventually they will support the society empowerment.

\subsubsection{The influence of Human Capital on Society Empowerment}

Based on the research result, it shows that human capital has positive influence on society empowerment. It can be seen from Table 1 that shows the value of human capital is 0,117 . It means that if the human capital is improved, it will strengthen the society empowerment. Human capital can be improved by developing the education level, health rate, and the ability to build interaction among the miners. Therefore, the better human capital is, the better society empowerment process will be.

\subsubsection{The influence of Social Capital on Society Empowerment}

Based on the research result, it shows that social capital has positive influence on society empowerment. It can be seen from Table 1 that shows the value of social capital is 0,228 . It means that if the social capital is increased, it will strengthen the society empowerment. Social capital needs to be maintained especially to build the social network, improve cooperation, trust to each other, be obedient to the norms, care of each other, and be involved in social organization activities. Therefore, the higher social capital they have, the more empowered the miners will be.

\subsubsection{The influence of Actors' Ability on Society Empowerment}

Based on the research result, it shows that actors' ability has positive influence on society empowerment. It can be seen from Table 1 that shows the value of actors' ability is 0,115 . It means that if the actors' ability is improved, it will strengthen the society empowerment. The actors' abilities that need to be improves include the miners' cognitive knowledge, affective behavior, and psychomotor skills. Therefore, the better actors' abilities are, the society will be more empowered.

\subsection{Conclusion}




\section{HPSCONF

This topic is crucial to be discussed in a research since it is expected that the society of Wonocolo understand well that there are many potentials in their region. The potentials do not only include the traditional oil mining, but also the tourism potentials that can serve as educational tourism. This condition may not occur in anywhere else. Therefore, the society is expected to be able to utilize the potentials in their region that is similar to the oil location in Texas, America. Thus, Teksas in Wonocolo becomes the educational tourism that serves as learning center about oil and how to exploit it. Besides, there is also adventure tourism to go around the region by Jeep.

The performance of the oil miners by reusing the oil wells cannot be fully expected to improve the economic condition of the miners' families. Therefore, the miners of the old wells in Wonocolo must be aware of the numerous tourism potentials that should be developed. They have to be able to utilize and develop the tourism potentials and create superior products of their region. Thus, society empowerment needs to be conducted. One of them is by conducting business training for the old wells miners so that they can increase their income.

Based on the result and discussion, it shows that:

1. The variables of the physical capital, human capital, social capital, and actors' ability have positive influence toward the society empowerment.

2. Social capital is the most dominant variable in influencing the society empowerment.

3. Actors' ability is the least leading variable since its influence has less significance to the society empowerment.

It is expected that from this research result, the local government of Bojonegoro can cooperate with the society in Wonocolo to improve the society empowerment.

\subsection{Acknowledgments and Legal Responsibility}

Our gratitude goes to Ministry of Education and Research of Indonesia for giving support and fund, and University of National Development "Veteran" Yogyakarta for supporting this research.

\section{References}

Aprillia Theresia.2014."Pembangunan Berbasis Masyrakat Acuan Bagi Praktisi, Akademisi, Pemerhati Pengembangan Masyarakat". Alfabeta. pp. 94.

Kussujaniatun, Sri. 2009. Analisis Strategi membangun Loyalitas konsumen melalui 
Differensiasi produk. (Survai pada pengguna sepeda motor "Yamaha Mio" di Kab Sleman) Seminar Nasional V Call for Paper UTY. ISBN: 978-979-1334-25-9, 18 juli 2009.

Kussujaniatun, Sri. 2014. Pengentasan Kemiskinan: Motivasi dan Budaya perempuan dalam mekanisme Pemberdayaan Perempuan berbasis Pendekatan potensi di Kecamatan Berbah Sleman. Seminar Nasional,Program Studi Manajemen Fakultas Ekonomi UPN "Veteran” Jogjakarta. Proceeding SINAU 3, 2014.

Kussujaniatun, S., Kismantoroadji T. 2017. Community Empowerment in Teak Root Potential Area (Study: Teak Roots Craftsmen in Margomulyo Bojonegoro, Indonesia). International Journal of Social Science and Humanity. Vol 7,(12), pp.756-761, December 2012.

Kussujaniatun, S., Kismantoroadji T. Tourism Potential Mapping Susing Ethnographic Approach: A Case of Margomulyo, Kabupaten Bojonegoro.Journal of Engineering and Applied Sciences Vol. 12 (21), pp. 5437-5442

Widjajanti, Kesi. 2011. Model Pemberdayaan Masyarakat. Jurnal Ekonomi Pembangunan.Vol. 12 pp15-27 